\title{
Between Three Seas: Borders, Migrations, Connections
}

\author{
Introduction to the Thematic Issue
}

\author{
Balázs Nagy \\ Eötvös Loránd University, Budapest, Hungary; Central European University, \\ Budapest - Vienna, Hungary - Austria \\ nagybal@ceu.edu \\ Katalin Szende \\ Central European University, Budapest - Vienna, Hungary - Austria \\ szendek@ceu.edu
}

\section{Going Medieval}

In the summer of 2015, the countries of Central and Southeastern Europe were faced with a massive wave of refugees caused by the collapse of the established political order in the Near East. In the longue durée, this was not a new phenomenon. Throughout the Middle Ages the region of Central Europe, closed off by the Baltic, Black and Adriatic Seas, was at numerous times exposed to the large-scale movements of people, whether migrations or invasions, while its borders as well as political and cultural landscapes were constantly shaped and reshaped anew. Yet during this entire period migrations were also taking place on a micro level. As various individuals, objects, and ideas circulated to and fro, political, economic and cultural connections emerged that transcended borders both within and beyond the region.

This quote is from the Call for Papers of the Third Biennial Conference of the Medieval Central Europe Research Network (MECERN) organized by the University of Zagreb in collaboration with the Croatian Institute of History in April 2018. In this issue we are offering a selection of the revised papers presented at this conference to the readership of the East Central Europe journal, a particularly appropriate venue for such a topic.

MECERN (http://mecern.eu/) was created in 2014 under the auspices of the Department of Medieval Studies of Central European University in 
Budapest as an interdisciplinary organizational framework fostering research into medieval Central Europe, as well as to offer a regular forum for the presentation of research results in the form of biennial conferences. After Budapest (2014), Olomouc (2016) and Zagreb (2018), the fourth one in Gdańsk (2020) examines the building of networks in Central Europe, as well as between Central Europe and the wider world.

This thematic issue in East Central Europe is the third one of its kind on medieval history, following some 25 years after the first two in the transitory volumes 20-23 (1993-1996), before the journal was taken over by Brill. The first instance was a general selection of articles by medievalists such as János M. Bak, Jenő Szűcs, József Deér, Gyula Kristó; the second one a fascicle on "Women and Power in East Central Europe," edited by the late Marianne Sághy (1961-2018). The current issue is hopefully the first act of a more regular "medieval presence" and co-operation between $E C E$ and MECERN. Besides seeking the attention of a medievalist audience, the guest editors of this issue also wish to appeal to the regular readers of this journal who are mainly researchers of modern periods. We envisage these articles to be not only an interesting intellectual excursion to past times but as contributions to constituting (or deconstructing) the region's image and identity. In fact, with this shortintroduction aswell as the selection of the articles, we intend to engage in the discussion on the validity of this regional distinction as an analytical category. Our view that events of the present or processes of the recent past can be better understood in a long-term perspective, however, does not mean enforcing continuities on the history of a region that is rather characterized by sharp turns and dramatic disruptions. Instead, we encourage our readers to discover strategies and patterns that may help us compare, contrast, and explain courses of action in chronologically distinct periods and under different social, political, and economic circumstances. In other words, by offering points of reference and comparison, we hope to arrive at a tighter-knit grouping of interpretations and a sharper view of our common ground, East Central Europe.

\section{Crusaders and Diplomats}

The seven articles presented in this thematic issue focus on the impact of both mass and individual movements in the region, particularly through the involvement of polities, religious orders, and single persons in military and diplomatic enterprises. The geographical framework reaches "from the Baltic to the Adriatic," and even the Mediterranean. The chronologies span some 300 years between the capture of Damietta in Egypt during the Fifth Crusade in 1219 (Benjámin Borbás) and the consecration of Bishop Johannes Kievel as the head of the Saare-Lääne Bishopric in Livonia in 1515 (Anu Mänd). 
One of the common themes across several articles (Benjámin Borbás, Tamás Ölbei, Sobiesław Szybkowski, Nicholas Youmans, Attila Bárány) is the involvement of the polities of East Central Europe in the Crusades. This participation followed out of geopolitical necessity, the region being on the way for the maritime and especially the land routes to the Holy Land. This position led to confrontation from the time of the First Crusade onwards, but also to an increased awareness of the existence and importance of these territories among the highest echelons of medieval society, secular as well as religious (Plumtree 2018). The northern part of the region, in its turn, was en route for the Baltic Crusades, and finally the late Crusades against the advance of the Ottoman Empire on the Balkans focused the crusaders' attention again in a southerly direction (Hunyadi and Laszlovszky 2001). Another constraint was the position of Venice as the bottleneck, imposing its monopoly of transport on the Adriatic to the utmost, against which, as Tamás Ölbei's article explains, the best remedy was using the land route. The connections worked both ways: East Central Europe became involved as logistic hinterland and potential participant in the military campaigns, and Crusader knights from all corners of Latin Christendom became acquainted with the lands they travelled through (see e.g. in relation to Hungary: Csukovits 2018: 22-25, 51-61).

The single most prominent protagonists of the Crusades in East Central Europe were the Teutonic Knights, or as they were officially called, the Order of Brothers of the German House of Saint Mary in Jerusalem. They shared the ambiguous lifestyle typical of military orders, representing both knightlysecular and monastic-religious values. How these values were played out in acts of military and missionary mobility as well as gestures of hospitality, following the inspiration of the performative turn, is examined here by Nicholas Youmans. Besides these general traits, the Teutonic Order was the par excellence "Central European" military order, as opposed to the Templars and the Hospitallers, with most of its houses around 1300 being located in the Holy Roman Empire. However, their most famous (or infamous) presence was in Prussia and Livonia, moving their point of gravity east by necessity and political constellation (Boockmann 2002, 2012). The study of the Teutonic Order still attracts considerable scholarly interest in Central Europe and all over in the world, as attested by the publications printed in the yearbook Ordines Militares-Colloquia Torunensia Historica.

The fact that King Andrew II of Hungary evicted the Order from Transylvania after barely fourteen years of presence (1211-1225), and that Konrad of Masovia subsequently invited them to help him in his fight against the then still pagan Prussians, had long-term consequences for European history up to the twentieth century (Czaja and Nowak 2015). The events discussed in Benjámin Borbás's article took place exactly in these decades, when the order was 
fighting to maintain its positions both in the Holy Land and in Prussia. The description of the discord concerning the distribution of war booty sheds a sharp light on the limited carrying capacity of Prussia and Livonia when it came to supporting crusading in the Holy Land.

The history of the following two centuries shows how both the knightly and the monastic character of the Teutonic Order transformed during its presence in East Central Europe, where these traits counted as "imported novelties" in the first place. The fact that the originally religious vow of the knights was turned into the service of power politics and conquest was partly due to the late Christianization of the region. The Prussians, Lithuanians, and other tribes by the Baltic Sea and the adjoining plains were the last pagan peoples of Europe, and their forced conversion offered the Order sufficient justification for creating its own state. The symbolic act of baptism of King Mindaugas of Lithuania presented in a propagandistic light by the chronicler of the Order, including a lavish exchange of gifts - discussed by Youmans - is a good example of this interpretation (see also Bojtár 1999: 176-179). The Order successfully employed means of symbolic communication well-known from other parts of Europe (Althoff 2015) to reinforce its political and military supremacy; the device "honor conquers all" given to the participants of the festive dinners at their headquarters in Malbork (Marienburg) was a well-chosen confirmation of the hard reality of conquest.

The fact that the Order was in a frontier location, exposed to other cultures, was also reflected in the composition of the Grand Master's entourage, which had to include a "pagan scribe," and three or more of the so-called Turkopols, light cavalrymen. Another liminal feature was the adoption of pagan burial rites, such as cremation burials, by the members of the Order if they died far away from their houses. The lenient attitude towards practices otherwise strictly forbidden to Christians might be explained by the difficulties of transporting uncremated human remains (Klavins 2006, quoted by Youmans). Reports on the adoption of other shamanistic cult elements by the knights, even if exaggerated, signaled that in a situation of contact, such excesses seemed to be imaginable. These accusations, however, ran contrary to the Order's intention and strategy of creating a sacred landscape as a result of their crusades (Leighton 2018).

The controversial situation of frontier zones and the difficulties in taking sides is thematized by the study on the nobility of Dobrzyń Land by Sobiesław Szybkowski. Dobrzyń Land was a territory bordering the Kingdom of Poland, the Teutonic State in Prussia, and the Duchy of Mazowsze (Masovia). Its fate is yet another example showing that the relatively late conquest and political organization of the land made it possible for the religious order of the Teutonic 
Knights to establish a strong secular state, be part of both crusader efforts, but also fight against the Christian monarch of Poland. The article raises thoughts about the fluidity of the definition of refugees and exile, forced or voluntary mobility.

The rule of the Teutonic Order brought along profound, although often unwanted, transformations on the urban scene as well. Błażej Śliwiński and Beata Możejko present the gruesome story of the "great massacre" at Gdańsk in 1308, which led to the re-establishment of the town on new foundations. The intrusion of the knights into the busy trading port, at first justified by the professed alliance with Duke Władysław Łokietek, ended with the use of brute force. This sequence of actions was mirrored when capturing the small town of Tczew. Traces of continuity such as the seal matrix of Gdańsk may induce further discussions on this issue and the discovery of further archaeological evidence may shed new light on the early topography of the city. Likewise, the new atlas of Gdańsk soon to be published in the framework of the European Atlas of Historic Towns project is also expected to offer new insights.

Cities of the Royal Prussian territories preserved much of their strength and autonomy after their parting with the Teutonic knights, under the nominal sovereignty of the Polish monarchs. These municipalities became part of a corporate model of governance, "and in the case of Danzig the tradition of self-governing rights continued well into the twentieth century" (Miller 2008: $156-163)$.

The Teutonic knights established a remarkably long-term presence in the northeastern borderlands of East Central Europe in other respects as well. They remained a significant power in the region even after their defeat by the Polish monarchs in 1410 and 1466, reflected, among other things, in the fact that they were still invited to the consecration ceremony of the bishops of Livonia until the victory of the Reformation, as Anu Mänd demonstrates in regard to the Saare-Lääne (Ösel-Wiek) Bishopric. From the viewpoint of networking, the case of this micro-bishopric on Europe's periphery shows perhaps even more than any central diocese how the Church as the single most overarching centralized institution across Europe manifested its influence. Strengthening papal and local episcopal authority was a reciprocal process, a "win-win situation" for both parties involved. One also encounters the Europewide pattern of intertwined ruling elites, with bishops hailing from the main landowning noble families. Mänd's article analyzes the pregnant visual representation of this entanglement of power. One of the stone reliefs is particularly telling: the coat of arms of Bishop Johannes IV Kievel displays a sword and a crozier (instead of the usual two croziers), and it was surely not by chance that the prelate used the term "coronation" for his inauguration ceremony. 
So far, this Introduction has concentrated mainly on the peripheries of East Central Europe. One must not forget, however, that between the Baltic and the Adriatic there was also a core, a territory whose resources filled in a gap in the European economy at a moment when the western part of the continent was in deep political, economic, and demographic crisis, in the fourteenth and the first half of the fifteenth century. Ölbei and Bárány demonstrate cases when exactly this central part of East Central Europe comes to the fore. Ölbei's study presents Louis I the Great, King of Hungar, Casimir III the Great, King of Poland and Charles IV, Emperor of the Holy Roman Empire as mighty and competent partners in an all-European enterprise of planning a crusade to the Holy Land in 1364-1366. It was not their fault, but due to a revolt in Crete against Venice, as well as other problems of logistics and coordination that the enterprise did not come to fruition.

Attila Bárány invites the readers to join the entourage of Sigismund, king of Hungary and the Romans. Despite all his controversial traits and miscarried attempts at stopping the Ottoman advance, as well as the reprehensible role that he played in Jan Hus's trial in Constance, Sigismund was a truly integrative personality in the European politics of his time (Hruza and Kaar 2012; Bauch et al. 2017). A unique feature of his rule was that in lacking Hausmacht in the Holy Roman Empire, he relied on the resources of his first and most stable crown, the Kingdom of Hungary, which he acquired already in 1387, 23 years before his election as King of the Romans in 1410. How his system of double governance developed when he was in charge of both Hungary and the Holy Roman Empire was analyzed in a dissertation recently defended by Márta Kondor at CEU (2017). Bárány examines here the question of Sigismund's foreign diplomacy, especially the diplomats and their achievements. The study, the appendix of which is likely to become a stable point of reference for further research, shows that Hungary not only provided Sigismund with much-needed financial hinterland to realize his Europe-wide plans, but also with the equally important "personal hinterland" of courtiers and diplomats. The success of Sigismund's courtiers in diplomacy proves that through a century of exposure to chivalric culture and warfare in Europe, the descendants of noble families of Hungary had grown into the elite circles of European diplomacy, just like their Bohemian peers did under Sigismund's father Charles IV.

\section{East Central Europe under Scrutiny}

Let us conclude by returning to the question of the concept of East Central Europe: Does it have the necessary quality or distinctiveness that makes it a 
useful analytical category? The heuristic value of this regional distinction has been a perennial topic of discussion both in the earlier literature (Szücs 1981; Berend 2012; Berend, Urbańczyk, Wiszewski 2013), in previous issues of this journal (Janowski, Iordachi, and Trencsényi 2005) and in the publications resulting from the first MECERN conference mentioned above. Nora Berend (2016) writes about "the mirage of East Central Europe" and argues for the "normality" of extending Europe-wide research to Central and Eastern Europe without the (self-)segregation of this region. János M. Bak (2016) points out that East Central Europe "is not an a priori category and that its definition (if one insists on having one) is fluid."

Nevertheless, as this selection of studies intends to demonstrate, this region does in fact merit special attention. East Central Europe, situated at the crossroads between the Holy Roman Empire, the Kievan Rus', and the actual great power of Southeast Europe, Byzantium and the later Ottoman Empire, was always a zone of interaction. Because of its geographical position, East Central Europe was frequented by foreign travelers heading to the Holy Land or returning from the Crusades, as some of the protagonists of these articles did. The commercial contacts of the region were also determined by its geographical location. The main navigable rivers, the Danube, the Vistula, the Oder and the Vltava-Elbe offered convenient commercial routes. The commercial expansion of the main Italian metropolises, Venice and Florence, and several others attained the markets of the countries of East Central Europe.

The countries of East Central Europe for the entirety of their historical development were populated by a multi-ethnic and multi-confessional population. This left a strong and lasting effect on the later development of the region. This territory was also exposed to the arrival of Christian and non-Christian migrants, the organized and natural migration of settlers, the process of which effected the ethnic structure of East Central Europe for a long time well beyond the Middle Ages. Urbanized settlements were characterized by the presence of a population of German origin throughout the region. Just as the population was varied, so were the forms of its movement, from voluntary migration to forced settlement, from the arrival of individuals or groups of settlers to their exile and expulsion. These movements were often triggered by military campaigns and wartime events, but many of their broader implications also applied in times of peace. Even if the great period of eastward expansion was the thirteenth century, migration continued at a slower pace in later times, just like the more ephemeral contacts of travel and exchange. These contacts and networks, the main theme of the next MECERN conference in Gdańsk have potential to provide further insight for forthcoming issues of this journal. 
Instead of a firm and definitive statement on the image of East Central Europe emerging from the studies collected here, we propose ending with a riddle. According to the bon mot attributed to Erik Fügedi, the renowned Hungarian medievalist (1916-1992), "Hungarian feudalism was like European feudalism, only all the details were different." If we exchange "feudalism" for "migration, exile, crusading, or diplomacy," can this assumption be extrapolated to East Central Europe? We leave it to the attentive reader to decide if indeed "all the details were different," and if the differences discovered add up to a meaningful distinction.

\section{Bibliography}

Althoff, Gerd. 2015. "Symbolic Communication and Medieval Order: Strengths and Weaknesses of Ambiguous Signs." In Rituals, Performatives, and Political Order in Northern Europe, c. 650-1350, edited by Wojtek Jezierski et al., 63-75. Turnhout: Brepols.

Bak, János M. 2016. “What Did We Learn? What Is to be Done?” In Medieval East Central Europe in a Comparative Perspective: From Frontier Zones to Lands in Focus, edited by Gerhard Jaritz and Katalin Szende, 254-256. New York: Routledge.

Bauch, Martin, Julia Burkhardt, Tomáš Gaudek, and Václav Žůrek, eds. 2017. Heilige, Helden, Wüteriche: Herrschaftsstile der Luxemburger (1308-1437). Cologne: Böhlau.

Berend, Nora, ed. 2012. The Expansion of Central Europe in the Middle Ages. Farnham: Ashgate.

Berend, Nora. 2016. "The Mirage of East Central Europe: Historical Regions in a Comparative Perspective." In Medieval East Central Europe in a Comparative Perspective: From Frontier Zones to Lands in Focus, edited by Gerhard Jaritz and Katalin Szende, 9-23. New York: Routledge.

Berend, Nora, Przemysław Urbańczyk, and Przemysław Wiszewski. 2013. Central Europe in the High Middle Ages: Bohemia, Hungary and Poland c.9oo-c.13oo. Cambridge: Cambridge University Press.

Bojtár, Endre. 1999. Foreword to the Past: A Cultural History of the Baltic People. Budapest: CEU Press.

Boockmann, Hartmut. 2002. Deutsche Geschichte im Osten Europas. Ostpreußen und Westpreußen. Munich: Siedler.

Boockmann, Hartmut. 2012. Der Deutsche Orden. 12 Kapitel aus seiner Geschichte. 5th ed. Munich: Beck.

Csukovits, Enikő. 2018. Hungary and the Hungarians: Western Europe's View in the Middle Ages. Rome: Viella. 
Czaja, Roman, and Zenon Hubert Nowak. 2015. "An Attempt to Characterise the State of the Teutonic Knights in Prussia." In The Teutonic Order in Prussia and Livonia: The Political and Ecclesiastical Structures, 13th-16th C., edited by Roman Czaja and Andrzej Radzimiński, 13-30. Toruń and Vienna: Towarzystwo Naukowe w Toruniu and Böhlau Verlag.

Hruza, Karel, and Alexandra Kaar, eds. 2012. Kaiser Sigismund (1368-1437): zur Herrschaftspraxis eines europäischen Monarchen. Vienna: Böhlau.

Hunyadi, Zsolt, and József Laszlovszky, eds. 2001. The Crusades and the Military Orders: Expanding the Frontiers of Medieval Latin Christianity. Budapest: CEU Press.

Janowski, Maciej, Constantin Iordachi and Balázs Trencsényi. 2005. "Why Bother about Historical Regions? Debates over Central Europe in Hungary, Poland and Romania." East Central Europe 32: 5-58.

Klavinš, Kaspars. 2006. "The Ideology of Christianity and Pagan Practice among the Teutonic Knights: The Case of the Baltic Region." Journal of Baltic Studies 37: 26o-276.

Kondor, Márta. 2017. "The Ginger Fox's Two Crowns: Central Administration and Government in Sigismund of Luxembourg's Realms 1410-1419." PhD Dissertation, Central European University, Budapest.

Leighton, Gregory. 2018. "Did the Teutonic Order Create a Sacred Landscape in Thirteenth-century Prussia?" Journal of Medieval History 44, no. 4: 457-483.

Miller, Jaroslav. 2008. Urban Societies in East-Central Europe, 1500-1700. Burlington: Ashgate.

Plumtree, James. 2018. “Charlemagne's Road, God's Threshing Floor: Comprehending the Role of Hungary in the First Crusade." Hungarian Studies 32, no. 1:1-26.

Szűcs, Jenő. 1981. "Vázlat Európa három történeti régiójáról." Történelmi Szemle, 313359. In English translation: "The Three Historical Regions of Europe: an Outline." Acta Historica Academiae Scientiarum Hungariae 29 (1983): 131-184. 